\title{
Monetary Policy Regimes and the Real Interest Rate
}

\author{
William T. Gavin
}

\begin{abstract}
During the period from 1965 to the end of 2015, the Federal Reserve operated monetary policy in a variety of ways associated with four distinct monetary policy regimes. These different monetary policy regimes display different outcomes for inflation, interest rates, and real consumption growth. This article uses the differences among the outcomes to better understand how monetary policy affects those outcomes. One of the important results is that monetary policy appears to be able to affect longterm real interest rates and real consumption growth during periods of extreme monetary policy in which the Fed holds short-term interest rates abnormally high or abnormally low for an extended period. This article exploits the idea of monetary policy regimes to ask whether monetary policy exacerbated the low real interest rate on safe assets and the low level of consumption during the period in which the range for the Fed's interest rate target was set at 0 to 0.25 percent. Many observers have appealed to real factors such as aging demographics to explain the low level of long-term interest rates. The evidence presented here suggests that policy analysts should also consider the possibility that the Fed was the main cause of the low real interest rate following the 2007-08 financial crisis. (JEL E43, E52, E58, E65)
\end{abstract}

Federal Reserve Bank of St. Louis Review, Second Quarter 2018, 100(2), pp. 151-69. https://doi.org/10.20955/r.2018.151-69

$\mathbf{T}$ he goal of this article is to ask whether monetary policy is a cause of the low real interest rate on safe assets since the onset of the 2007-08 financial crisis. The Federal Reserve uses its monopoly on bank reserves to lower interest rates when it wants to stimulate the economy. But many observers attribute the low real interest rate to real factors such as aging demographics and an upsurge in the demand for safe assets. Such factors would be associated with expectations of lower economic growth in the future. Are real rates low because future growth is expected to be low or because the Fed is holding short-term rates on bank reserves low? In other words, are low interest rates in the United States and around the world caused by Fed policy? This article exploits the idea of monetary policy regimes to shed light on this issue.

William T. Gavin is an economist emeritus of the Research Department at the Federal Reserve Bank of St. Louis. He thanks the economics faculty at the University of Guanajuato, Mexico, for their comments, questions, and support. This work was begun while he was a visiting professor there in 2016-17.

(c) 2018, Federal Reserve Bank of St. Louis. The views expressed in this article are those of the author(s) and do not necessarily reflect the views of the Federal Reserve System, the Board of Governors, or the regional Federal Reserve Banks. Articles may be reprinted, reproduced, published, distributed, displayed, and transmitted in their entirety if copyright notice, author name(s), and full citation are included. Abstracts, synopses, and other derivative works may be made only with prior written permission of the Federal Reserve Bank of St. Louis. 
The idea of a monetary policy regime is somewhat vague. It is related to the idea of a monetary standard. Examples of monetary standards include the classical gold standard that existed in most developed economies between 1880 and 1914, the modified dollar-gold standard adopted in 1946-the Bretton Woods agreement-and the paper money standard that evolved after the Bretton Woods agreement began to come apart during the 1960s. This paper examines distinct U.S. policy regimes that were adopted to manage a paper money standard. The regimes are defined by the different goals for policy and by the different procedures used to implement monetary policy decisions. 1 The Fed has a dual mandate to promote price stability and full employment. In practice, price stability is defined as 2 percent inflation. Achieving the full employment goal is more problematic because the concept of full employment is not measured directly. This part of the dual mandate is implemented by following a countercyclical policy, easing policy when the economy is thought to be below its potential and restricting policy when the economy is estimated to be growing above its sustainable long-run trend. In making decisions at Federal Open Market Committee (FOMC) meetings, the participants look at everything, but the two most important economic indicators are inflation and real gross domestic product (GDP) growth. $\underline{2}$

In defining the Fed's monetary policy regimes in this way, the distinctions among them depend on the relative emphasis given to price stability versus business cycle stabilization at policy meetings. The differences between regimes can be seen in the outcomes for inflation and nominal interest rates.

\section{REAL EFFECTS OF MONETARY POLICY}

Typically, we do not think about different monetary policy regimes leading to different equilibrium levels of real interest rates or real GDP. Our most basic theories of money assume the classical dichotomy - real variables are determined by real factors and nominal variables are determined by monetary policy. Even Keynesian models with sticky prices assume that the real effects are short-lived-a few quarters at most. For monetary policy to have persistent real effects, we have to consider extreme policies or extend the models to include more realistic features.

The most well-studied example of extreme monetary policy is hyperinflation - very high inflation that causes firms to change prices daily and consumers to hold as little currency as possible. It reduces real interest rates and real economic activity because the hyperinflation interferes with the price mechanism that is key to equilibrium adjustments and efficiency in market-based economies. Hyperinflations rarely persist for too long because the effects are so bad that they bring down governments that are not willing or able to bring about reform.

Another example of an extreme monetary policy was the Volcker monetary reform that ended the high inflation of the 1970s with extremely high federal funds rates. This was an extreme policy that led to high nominal and high real interest rates. But this policy also could not last too long because the high and volatile interest rates were very disruptive to the economy. The current policy regime is also extreme-because the interest rate policy is not consistent with the 2 percent inflation objective. This policy has led to persistently low real rates on bank 
reserves and other safe assets. It is also possible that it has led to a low level of real economic activity.

Gavin et al. (2015) use a nonlinear solution to a standard New Keynesian model to show that a persistently low interest rate can lead to a path for output that is persistently below the model's equilibrium steady state. The theory assumes that the equilibrium real interest rate is equal to the sum of the growth rate of consumption and the rate of time preference (everything else equal, the rate at which people are indifferent between current and future consumption). If some factor keeps the interest rate below the equilibrium level, then the amount that people want to borrow will exceed the amount that people want to save. If the interest rate cannot adjust upward to achieve equilibrium in the market for loanable funds, then income will fall until the amount people want to borrow equals the amount people want to save. $\frac{3}{\text { Assuming }}$ that monetary policy can affect the real return to saving, then a persistently low interest rate policy will lead to persistently subpar economic activity. The optimal level of economic activity can be achieved only when the real interest rate returns to a normal level associated with the growth rate of consumption plus the rate of time preference. ${ }^{4}$

Gavin et al. (2015) do not explicitly consider policy as the cause of the unusually low interest rate. To model policy in a zero interest rate environment, one has to consider a more complex model that takes account of the government's budget policy. In most monetary policy models, the price level is determined by monetary policy. The government's intertemporal budget constraint was not part of these models because fiscal policy was assumed to always accommodate monetary policy. But this assumption leads to mistaken analysis when the interest rate is stuck at the zero lower bound. Monetary policy is fixed, and fiscal policy, by default, becomes dominant. Building models that incorporate monetary and fiscal policy into a general theory of the price level (an area of research that is generally known as the fiscal theory of the price level) is a topic too advanced to explain in this Review article. ${ }^{5}$ For a recent paper that develops this theory in a small model, see Andolfatto and Martin (2017).

This article attempts to explain why the zero interest rate policy followed in the aftermath of the 2007-08 financial crisis is an extreme policy. The key assumption made is that the rate of time preference is relatively invariant over time and exogenous with respect to monetary policy. An alternative that forms the basis of Bullard (2017) is that the growth rate of labor productivity is exogenous with respect to monetary policy. Of course, the rate of time preference is not observable, although the growth rate of labor productivity is. But there is no reason to think that the rate of time preference suddenly fell with the financial crisis. On the other hand, there is a good reason to question whether the growth rate of labor productivity is independent of the monetary policy regime. The reason is simply the behavior of turnover (in both jobs and firms) since the onset of the zero interest rate policy and the empirical evidence showing that higher turnover is generally associated with higher productivity growth.

A significant anomaly in the post-crisis period of low interest rate policy has been very low levels of turnover, levels typically associated with being in a recession with low productivity growth. - Old inefficient firms tend to go out of business during recessions and are replaced during the recovery by new firms using more efficient technology. Foster, Grim, and Haltiwanger (2016) find that since the 2007-08 financial crisis and 2007-09 recession, 
measures of turnover have yet to fully recover from the recession levels. They suggest that inefficiencies in credit markets may be part of the problem. In any case, it seems possible that the low productivity growth rate and reduced turnover of jobs and firms are not exogenous with respect to a monetary policy that pegs the interest rate near zero.

\section{FOUR MONETARY POLICY REGIMES}

This article characterizes a monetary regime by two properties: (i) the weight policymakers put on price stability relative to their concern about output stabilization and (ii) the day-to-day procedures used to implement policy. This paper defines four distinct regimes implemented by the Federal Reserve since the mid-1960s. Each regime is associated with different policy objectives, different operating procedures, and different statistical patterns in the data.

The four regimes are as follows:

(i) The Great Inflation: January 1965-October 1979, a period with an interest rate targeting procedure and a rising trend in both inflation and interest rates. Although policymakers expressed concern for price stability, their actions focused on business cycle stabilization and allowed inflation to become high and volatile.

(ii) The Volcker Reform: October 1979-October 1982, a short period in which a money supply (M1) targeting procedure was used to stop the acceleration of inflation and earn credibility for the price objective. Concern for output stabilization was dominated by the desire to end high inflation and gain credibility for price stability.

(iii) The Great Moderation: October 1982-December 2008, a period in which the Federal Reserve used interest rate targeting procedures to maintain the credibility for low inflation that was achieved in the second regime. The concerns were about evenly divided between price stability and output stabilization, as revealed in the Taylor-type interest rate rules used to describe policy during this period.

(iv) Zero Interest Rate Policy (ZIRP): December 2008-December 2015, a seven-year period in which the target range for the federal funds rate was pegged between 0 and 0.25 percent. The market was flooded with trillions of dollars of excess reserves as banks earned 0.25 percent on reserve balances at the Fed. The main concern was output stabilization, as output appeared to grow along a path that was considered to be well below the potential for GDP. Inflation tended to remain below the Fed's 2 percent long-term objective.

I study these four episodes, briefly describing the operating procedure and documenting statistics that are important for estimating business cycle and inflation dynamics. I find important and predictable differences in dynamic patterns across the four separate regimes.

\section{The Data}

I study four monthly economic indicators over the period January 1965-December 2015. They include the effective federal funds rate $(F F)$, the yield on 10 -year government securities (GS10), year-over-year inflation in the consumer price index (CPI), and the growth rate of 
real per capita personal consumption expenditures $(\mathrm{Cdot})$. The fundamental policy goals involve inflation and real economic activity, hence the inclusion of $C P I$ and Cdot. ${ }^{7}$ The policy instrument is $F F$. Once $F F$ hits the zero lower bound, the FOMC uses balance-sheet policies to lower rates on long-term assets represented here by GS10.

I also look at some combinations of these four indicators: the spread between the two interest rates, FF-GS10 (Spread); the ex post real federal funds rate, FF-CPI ( $r F F$ ); the ex post real 10-year bond rate, GS10-CPI ( $r$ GS10); and the gap between the real federal funds rate and the real per capita growth rate of consumption, $r F F-C d o t$ (Rgap). The spread between FF and GS10 has often been used as an indicator of the stance of monetary policy. Since it is the real rates that go into the theoretical models, real versions of these policy instruments are also included. The Rgap variable is based on consumption growth because modern models in macroeconomics and finance generally include an equilibrium condition that makes the risk-free real interest rate converge approximately to Cdot plus the rate of time preference.

\section{The Regimes}

The Great Inflation. The Great Inflation began with the collapse of the dollar-gold standard established by the Bretton Woods agreement. $\stackrel{8}{ }$ Much has been written about why inflation became such an important policy problem. Nelson (2005) blames the policy community for not understanding the role of money in causing inflation, instead viewing inflation as being caused by supply shocks and excess demand for labor and goods in a Phillips-curve framework. Delong (1997) argues that the Phillips-curve framework was fine, but that the Fed used errorridden measures of potential output and real interest rates that caused it to keep interest rates too low, too often. Sargent (2002) argues that the problem was that policymakers ignored modern advances in macroeconomic theory when implementing policy using the Phillipscurve framework. ${ }^{9}$ Figure 1 shows that the year-over-year inflation rate rose from around 2 percent in 1965 to above 13 percent in 1980.

Figure 2 depicts interest rates. During the Great Inflation, the relationship between $F F$ and GS10 displays three distinct features. First, both interest rates display rising trends and, on average, are roughly equal: FF was just 28 basis points below GS10 (see Table 1 for regime averages). Second, the policy rate was sometimes as much as 2 percentage points higher or lower than the bond rate. Third, periods with a relatively low policy rate were followed by higher inflation and inflation expectations, reflected in rising bond rates. Also, periods with a relatively high policy rate were followed by lower inflation and recession.

The lack of credibility made setting the policy rate above the bond rate necessary to reduce inflation expectations. When the FOMC raised the policy rate too slowly, inflation expectations would rise to match the rise in the interest rate, and there was no dampening effect on either the economy or inflation. The lack of credibility meant that to succeed in lowering inflation, the FOMC had to raise the policy rate high enough to slow the economy. This led to a belief that raising interest rates would likely lead to recession. A corollary to this idea was that low interest rates would end the recession and stimulate both inflation and economic expansion. What has not been generally recognized is that these dynamic relationships came to be part of conventional wisdom in macroeconomics during a time when the Fed had no 
Figure 1

\section{Inflation in the United States (CPI)}

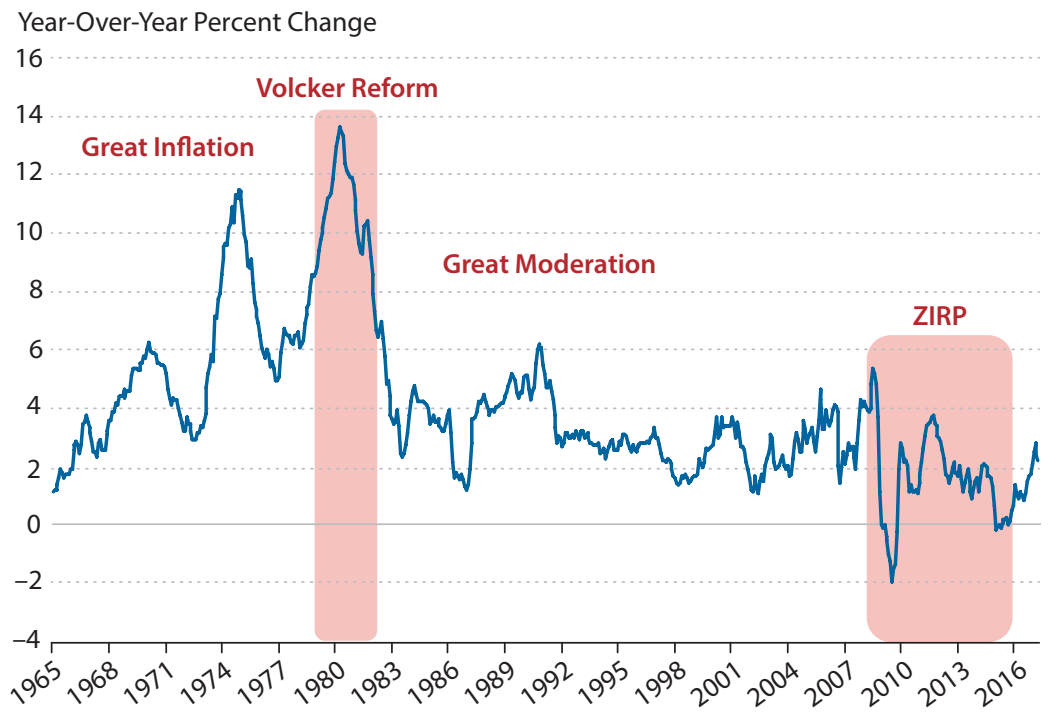

SOURCE: FRED ${ }^{\oplus}$, Federal Reserve Bank of St. Louis, CPIAUCSL, and author's calculations.

Figure 2

The Federal Funds Rate (FF) and Yield on 10-Year Treasury Bonds (GS10)

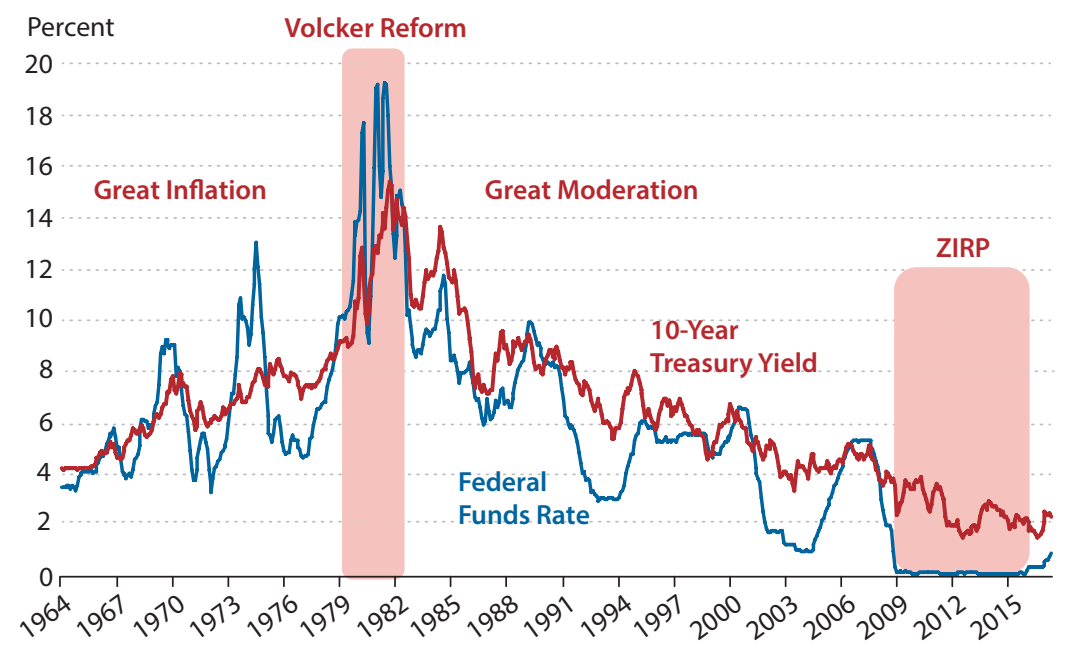

SOURCE: FRED ${ }^{\circledR}$, Federal Reserve Bank of St. Louis, FEDFUNDS and GS10. 
Figure 3

Volatility in the Yield on 10-Year Treasury Bonds (GS10) (standard deviation of 7-month moving average)

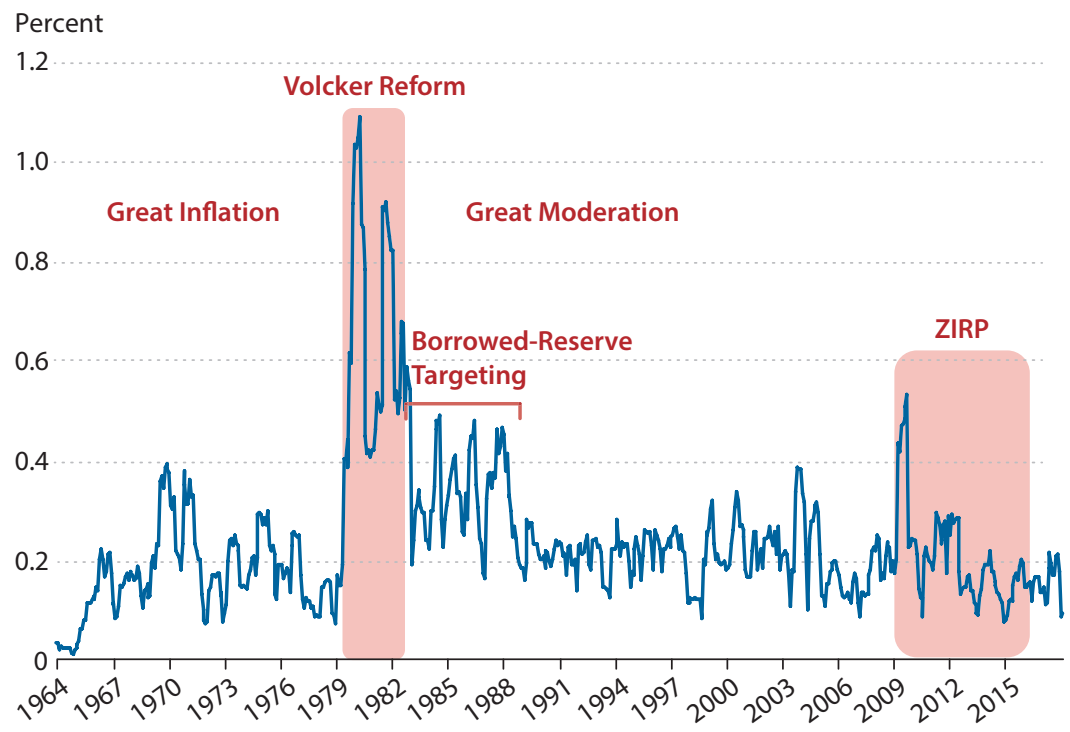

SOURCE: FRED ${ }^{\circledR}$, Federal Reserve Bank of St. Louis, GS10, and author's calculations.

\section{Table 1}

Average Values in Each Regime (percent)

\begin{tabular}{lcccr} 
& $\begin{array}{c}\text { Great } \\
\text { Inflation }\end{array}$ & $\begin{array}{c}\text { Volcker } \\
\text { reform }\end{array}$ & $\begin{array}{c}\text { Great } \\
\text { Moderation }\end{array}$ & ZIRP \\
\hline Federal funds rate (FF) & 6.43 & 14.36 & 5.36 & 0.13 \\
Yield on 10-year bonds (GS10) & 6.71 & 12.77 & 6.79 & 2.58 \\
Inflation (CPI) & 5.55 & 10.15 & 3.10 & 1.38 \\
Real per capita consumption growth (Cdot) & 2.06 & -0.85 & 2.27 & 0.57 \\
FF-GS10 (Spread) & -0.28 & 1.58 & -1.42 & -2.45 \\
FF-CPI (rFF) & 0.88 & 4.20 & 2.27 & -1.25 \\
GS10-CPI (rGS10) & 1.16 & 2.62 & 3.69 & 1.21 \\
rFF-Cdot (Rgap) & -1.17 & 5.06 & 0.01 & -1.87 \\
\hline
\end{tabular}

credibility for its inflation objective. High inflation together with high unemployment challenged this conventional wisdom and, at least temporarily, discredited the Phillips curve as a policy framework.

The Volcker Reform. $\underline{10}$ The change in conventional wisdom gave Fed Chairman Paul Volcker the cover to adopt an operating procedure based on money supply targeting. He needed that cover because the new procedure led immediately to high and volatile interest 
Table 2

\begin{tabular}{lcccc}
\multicolumn{4}{l}{ Volatility (standard deviation of monthly changes in each regime, percent) } \\
& $\begin{array}{c}\text { Great } \\
\text { Inflation }\end{array}$ & $\begin{array}{c}\text { Volcker } \\
\text { reform }\end{array}$ & $\begin{array}{c}\text { Great } \\
\text { Moderation }\end{array}$ & ZIRP \\
\hline Federal funds rate (FF) & 0.44 & 1.92 & 0.25 & 0.02 \\
Yield on 10-year bonds (GS10) & 0.20 & 0.72 & 0.28 & 0.20 \\
Inflation (CPI) & 0.33 & 0.46 & 0.37 & 0.42 \\
Real per capita consumption growth (Cdot) & 0.89 & 0.84 & 0.70 & 0.40 \\
\hline
\end{tabular}

rates. This short regime lasted just three years but included two recessions separated by a very short expansion. Figure 1 shows that inflation dropped rapidly from double digits in 1980 to around 3 percent by the end of 1982 . Figure 2 shows that the average $F F$ was much higher overall and relative to GS10 during the Volcker reform than in any other period. Inflation came down quickly, but interest rates stayed high throughout this regime and well into the next. Because this extreme policy disrupted the economy, consumption growth was much lower in this regime than in any other (see Figure 3 and Table 1).

The Fed used an indirect form of money supply targeting to implement the reform. By targeting the money supply, the Fed could rightly say that it was not setting high targets for interest rates, just implementing a growth path for money consistent with ending inflation. $\underline{11}$ The market was setting interest rates. However, the policy did not just lead to high interest rates; it also led to a quadrupling of the standard deviation of changes in FF and GS10 (see Figure 2 and Table 2).

The Great Moderation. In October 1982, the Fed abandoned the M1 targeting procedure and adopted an indirect form of interest rate targeting. The method used to implement interest rate targeting evolved over the next decade, becoming more explicit after 1987 when Alan Greenspan replaced Paul Volcker as head of the Fed. Monetary policy during this third policy regime was praised by policymakers, business leaders, and academic researchers because of the low volatility in both output and inflation. Stock and Watson (2003, p. 162) coined the term "great moderation." Bernanke (2004) popularized the term and attributed the relative stability of output growth and inflation to, among other things, good monetary policy.

In 1982, Chairman Volcker was not willing to admit that the Fed had gone back to an interest rate operating procedure because he felt that such a procedure was too susceptible to political influence and was one of the basic problems with policy during the Great Inflation. He officially adopted a target for borrowed reserves, but that was just an indirect form of interest rate targeting. Volatility in the policy rate dropped immediately but remained relatively high as the borrowed-reserves operating procedure introduced volatility around the federal funds rate target, which was a secret revealed only indirectly to the market. $\frac{12}{}$ Figures 2 and 3 show that the level and volatility of FF continued to decline throughout Volcker's tenure and dropped even further as Greenspan gave up the pretense that the Fed was not targeting FF.

Trends in interest rates were declining throughout much of the Great Moderation. When the economy went into recession, the FOMC lowered the federal funds rate target to stimulate 
the economy. The FOMC expected this to lead to higher inflation, but it did not. The recoveries were not as vigorous as those during the Great Inflation. As the economy expanded, the FOMC did not have to raise the federal funds rate target above the GS10. By the time that FF was approximately level with GS10, inflation and inflation expectations had moderated. So the policy during the Great Moderation was asymmetric: The FOMC eased aggressively when the economy was weak, but did not have to raise rates so much during expansions. The result was that the average FF was 128 basis points lower than the average GS10.

The signature characteristic of the Great Moderation was the reduced volatility of inflation and output. Table 2 shows that the standard deviation of changes in consumption growth (Cdot) fell to 0.70 percent during the Great Moderation, down from 0.89 percent during the Great Inflation and 0.84 percent during the Volcker reform. The biggest surprise for the Fed was that inflation did not accelerate in response to lower interest rates during two extended periods of low interest rates-the first from September 1992 to February 1994 and the second from 2002 to 2004. There was no need to invert the yield curve, raising FF well above GS10, to keep inflation under control. Another surprise for the Fed was the rebound of more-rapid economic growth in the 1990s. Figure 3 and Table 1 show that this was the regime with the highest per capita consumption growth. Note, however, that Cdot during the Great Inflation was not that much lower than during the Great Moderation.

During this period the FOMC adopted a risk-management approach to monetary policy. $\frac{13}{.}$ The idea was that the Fed would forecast the future, taking account of all potential scenarios. To find the policy setting, they would look at the probability of each scenario occurring, such as a replay of the Great Depression or the Great Inflation. Then they would estimate the cost of each bad outcome. The weight of each scenario in setting the policy rate would be a product of the likelihood of the event occurring times the magnitude of the economic costs if that outcome occurred. The Fed viewed a lower interest rate setting as insurance against the outcome of all bad events except inflation. In the Fed's policy framework, the only important downside to low interest rates was the possibility of inflation. If there was no inflation, then interest rates probably were not too low.

The financial crisis raised awareness of another downside to low interest rates. The abuses in the mortgage market were due to many factors, but many observers attributed the sheer volume of bad debt to low interest rates. $\underline{\underline{14}}$ Today, the Federal Reserve takes responsibility for financial stability, but, as a practical matter, interest rate policy is aimed at stabilizing output and targeting inflation. Although the FOMC regularly monitors financial markets for evidence of financial instability, it has emphasized the use of macro-prudential policies to promote financial stability in an era of low interest rates.

The ZIRP. With the onset of the crisis, the Fed abruptly switched to the fourth monetary policy regime, the ZIRP regime. In response to the financial crisis, in September 2008, the Fed flooded the market with about $\$ 600$ billion in excess bank reserves and drove $F F$ toward zero. On December 16, 2008, the FOMC voted to set the bottom of the 25-basis-point target range for $F F$ at zero. It also adopted unconventional policies known as quantitative easing $(\mathrm{QE})$ and forward guidance that were intended to keep money market interest rates near zero for an extended period. $\frac{15}{}$ Although the Fed has a target range for $F F$, the actual policy rate set by 
the Fed is the interest rate on reserves (IOR). As it turns out, the period with the IOR set at the top of the target range for $F F$ ( 25 basis points) extended for exactly seven years. $\frac{16}{16}$

Both the level and the volatility of $F F$ went close to zero in September 2008 as the Fed flooded the money market with bank reserves (see Tables 1 and 2). Initially, the Fed supplied about $\$ 600$ billion in reserves mainly by making loans of 180 days or less. The Fed justified this action as insurance against the worldwide collapse of financial markets and a replay of the Great Depression. A review of Greenspan (2004) shows that this was an application of the "risk management" approach to monetary policy. However, whenever the Fed has "taken out insurance" against a bad outcome by lowering the federal funds rate target, it has been reluctant to raise interest rates back up to the pre-event levels. Generally, the Fed has shown an aversion to reversing interest rate movements within a short time span.

In the case of the financial crisis, the excess reserves could have naturally run off in about 6 months if the FOMC had not adopted the first instance of QE in December 2008. The rescue of financial institutions was funded by Fed loans and asset purchases with terms to maturity of 6 months or less. QE was an attempt to extend the expected time that the interest rate would stay near zero and an attempt to stimulate the economy by lowering longer-term interest rates. Later, the average maturity of assets on the Fed's balance sheet also rose as the FOMC rebalanced the portfolio, substituting long-term assets for short-term ones. Interest rates were also expected to stay low because it was the goal of policy suggested in FOMC post-meeting statements, policymaker speeches, and Congressional testimony. $\underline{17}$

In October 2008, the Federal Reserve had begun to pay interest on reserves. The IOR was set at the top of the federal funds target range and remained about 20 basis points above the discount rate on 3-month Treasury bills. This was a factor that increased banks' willingness to hold a large stock of excess reserves. Paying interest on excess reserves and supplying a large stock meant that the FOMC had switched from direct $F F$ targeting to a floor system. $\underline{18}$

There is a good example of a ZIRP regime in use in Japan since 1995. Cooke and Gavin (2015) show that the Japanese data can be used to estimate time-series models for the United States. Such use of Japanese data is unconventional, but I found that using these data-as if they were generated in the United States-delivered much better forecasts for U.S. GDP growth and long-term bond rates than using U.S. data from the Great Moderation. Of course, better $F F$ forecasts using Japanese data are to be expected because both countries were pegging their policy rates near zero. The inflation forecasts were about equally bad. The Japanese data predicted that inflation would be lower than it was, and the Great Moderation data predicted that inflation would be higher than the actual outcome.

Table 1 shows that the averages for all four indicators were much lower during the ZIRP regime than during the Great Moderation. Table 2 shows this is also true for the volatility of interest rates and inflation. The standard deviation of changes in the inflation rate is highest during the Volcker reform, during which inflation fell by 10 percentage points in 3 years. The volatility of $C d o t$ was highest during the two regimes in which interest rate policy was the most extreme, the Volcker reform and the ZIRP.

An important feature of the ZIRP regime, which began with a big two-quarter decline in consumption, is the failure of the economy to return to the trend in potential GDP that had 
been estimated by both the Fed staff and the Congressional Budget Office. The Fed and private forecasters incorrectly forecasted a return to trend over the next seven years. One response was to lower estimates of the level and growth rate of potential GDP. In the policy response, the Fed turned to QE twice more, taking the balance sheet to $\$ 4.6$ trillion by 2014 . The end of the ZIRP regime is assumed to have occurred when the FOMC voted to raise the federal funds rate target range by 25 basis points in December 2015.

\section{DYNAMIC INTERACTIONS AMONG CONSUMPTION, INTEREST RATES, AND INFLATION}

Policymakers place a large value on models that "fit the data." Econometric methods extract information from the dynamic variance-covariance structure of data. Gavin and Kydland $(1999,2000)$ show that the Volcker reform that made the inflation objective credible introduced statistically significant changes in the variance-covariance structure of datasets that include nominal indicators. It was also generally true that there did not appear to be significant changes in the variance-covariance structure of datasets that included only real quantities such as consumption, investment, or labor.

Figure 4 reports the cross-correlations between Cdot and three nominal variables, CPI, $F F$, and GS10. I calculate the monthly correlations from a six-month lead to a six-month lag. I also report the autocorrelation function for Cdot. I report results for the Volcker reform for completeness, but the sample is short and I think the one important fact about this regime is that it is an extreme regime in which the Fed tried to keep FF well above the normal rate. The intention was to keep the rate high until people became convinced that the Fed was serious about ending inflation. We do not expect to go back to that regime. We also do not expect to go back to the Great Inflation regime. The results clearly suggest that the monetary policy regime has important effects on the variance-covariance structure of the data that are important for estimating the relationships between interest rates and the economy.

FF and GS10 were both procyclical during the period of the Great Moderation and become countercyclical during the ZIRP regime. Inflation was procyclical during the ZIRP regime, but it was countercyclical during the Great Moderation. Models relating interest rates to consumption growth and inflation that were estimated using data from the Great Moderation would be expected to forecast poorly during the ZIRP regime. Only the persistence in consumption growth seems to be independent of the policy regime (again, leaving out the threeyear Volcker reform).

The cross-correlations of interest rates with inflation are shown in Figure 5. Of course, there is only very small variation in FF in the ZIRP regime, so more emphasis is put on GS10. The long rate was procyclical with consumption during the Great Moderation, but that positive correlation turns negative during the ZIRP regime. It is also shown that the cross-correlation between the Spread and CPI was strongly positive during the Great Inflation but fell during the Great Moderation. 


\section{Figure 4}

\section{Cross Correlations with Consumption Growth (Cdot)}

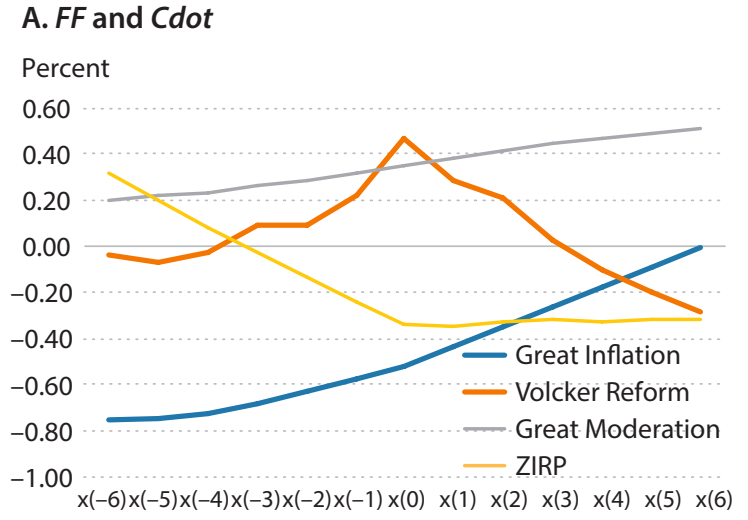

\section{CPI and Cdot}

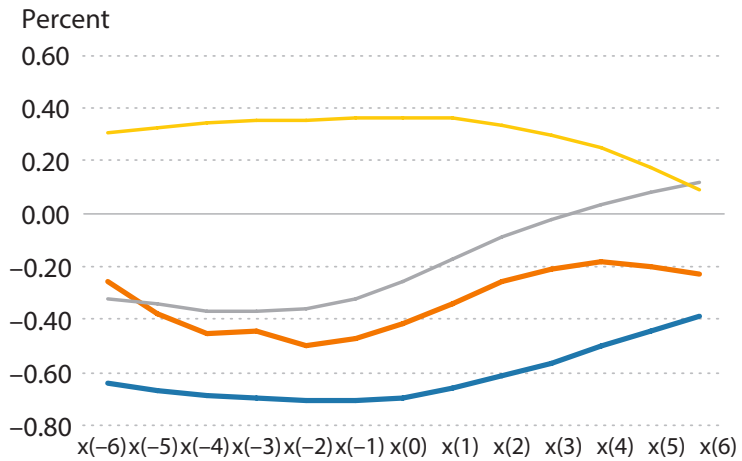

\section{B. GS10 and Cdot}

Percent

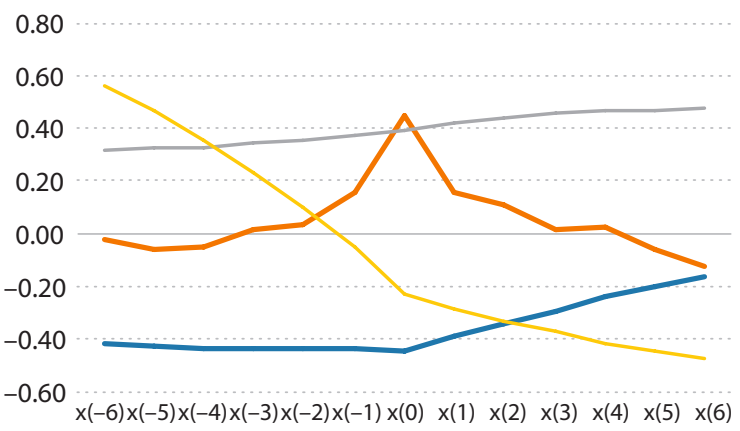

\section{Cdot and Cdot}

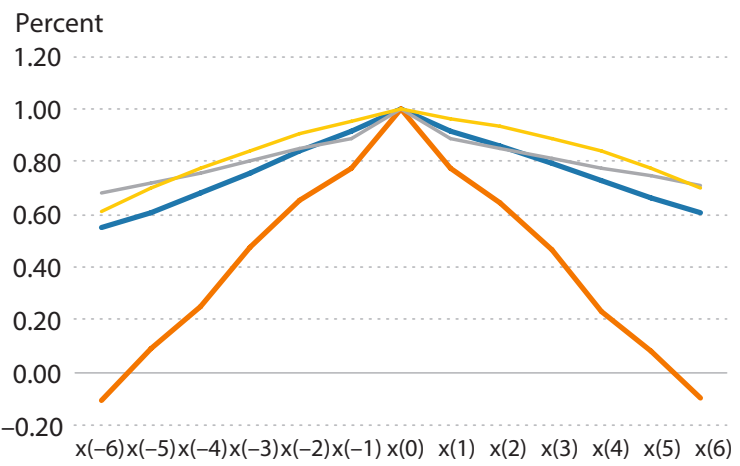

\section{ISSUES SURROUNDING MONETARY REGIMES}

Two important issues arose during the ZIRP regime-controversy surrounding the use of the Fisher equation to explain low inflation and controversy over the cause of low real interest rates. I introduce the idea of using Cdot as an independent measure of the equilibrium real interest rate. $\frac{19}{} \mathrm{I}$ also ask whether it is reasonable to think that monetary policy itself is the cause of the low natural rate estimated by Federal Reserve economists.

\section{The Fisher Equation}

The Fisher equation is an equilibrium condition that says that, no matter which policy regime is in effect, the market interest rate will be the sum of two components, a real return and a premium for expected inflation. If the Fed pegs the interest rate at any level, including zero, then an increase in real returns will lead to a decline in inflation. If the policy rate is 


\section{Figure 5}

\section{Cross Correlations with Inflation (CPI)}

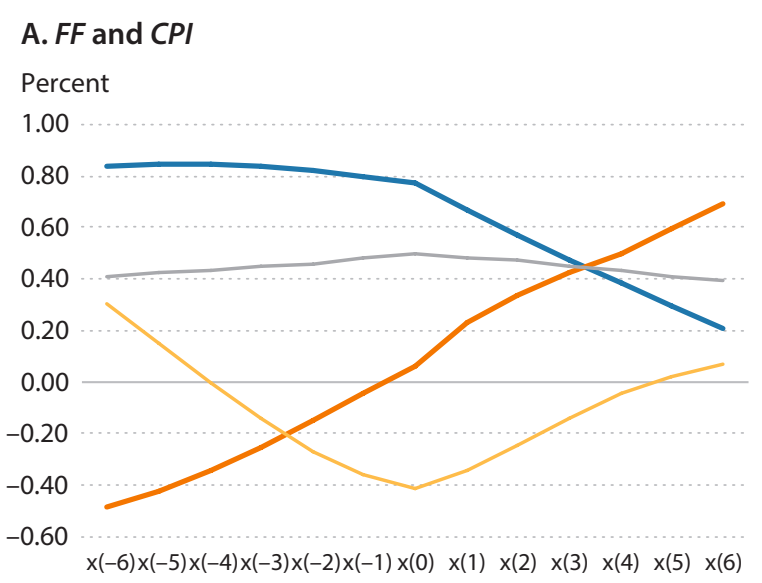

\section{Spread and CPI}

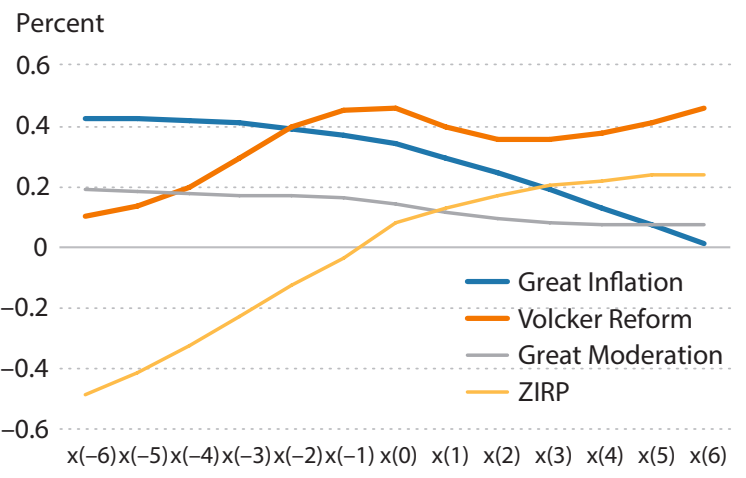

\section{B. GS10 and CPI}

Percent

1.00

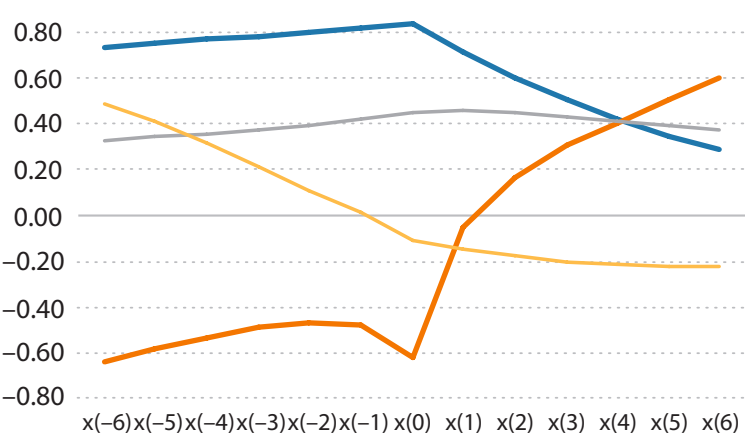

\section{D. $C P I$ and $C P I$}

Percent

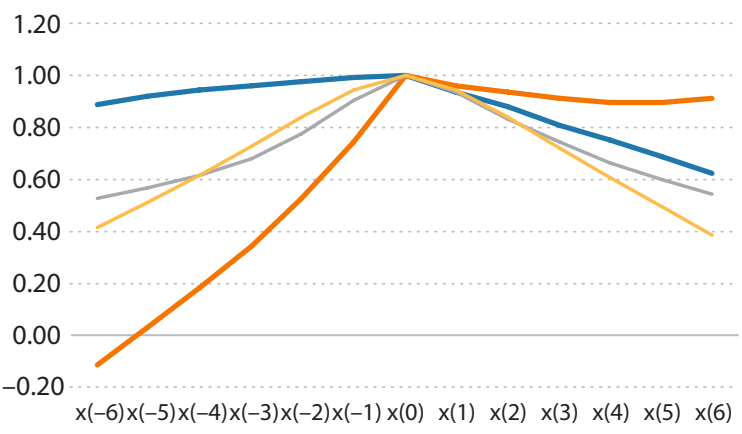

SOURCE: Author's calculations using the data in Figures 1, 2, and 6.

pegged at a higher level, the inflation rate will be higher. The equilibrium condition says nothing about what will happen in the short run if the Fed changes its policy rule. The opposition by business and policy economists to raising interest rates is based on beliefs about economic dynamics that were learned during the Great Inflation. These beliefs are imposed as maintained assumptions in large econometric models, but they are not obvious in post-1983 data. Such models do not impose the equilibrium condition known as the Fisher equation and produce forecasting errors when low rates do not produce higher inflation. $\underline{\underline{20}}$

\section{Real Interest Rates}

In theory, real interest rates matter for real economic activity because they influence consumption and savings decisions. Higher real interest rates reflect high returns to investment, and high returns to working now for consumption in the future. They also reflect the 
opportunity cost of building capital. Periods with low expectations for the future are periods of low interest rates. $\underline{21}$

As shown in Table 1, ex post real interest rates were quite low during the Great Inflation, the $r F F$ averaged 0.88 percent, while the $r G S 10$ averaged 1.16 percent. This was a period of slowing productivity growth. It was also a period when people were devoting many resources to protecting themselves from the damage done by inflation. Nevertheless, $C d o t$ was relatively high, just slightly above 2 percent. The three years of the Volcker reform were three years of high real interest rates. The $r F F$ was 4.2 percent, well above the $r G S 10$ rate of 2.62 percent. Note, however, that during the Great Moderation, the $r F F$ fell by about half, to 2.27 percent, while the average real return to holding a GS10 rose to 3.69 percent. During the ZIRP regime, following the crisis, $r F F$ fell to -1.25 percent, while the return to holding a GS10 fell to 1.21 percent.

\section{How Should We Measure the Counterfactual Equilibrium Real Interest Rate?}

What would the real interest rate on federal funds and 10-year Treasury securities be if the Fed were not following the ZIRP regime? The Federal Reserve uses its monopoly on bank reserves to lower interest rates when it wants to lower the cost of capital. This presents a real problem for the analyst. Are real rates low because future growth is expected to be low or because the Fed is holding short-term rates on bank reserves low? In other words, are low interest rates in the United States and around the world caused by Fed policy? To answer this question we need a measure of the equilibrium real interest rate that is not taken from observed market interest rates. The measure used in this section, the growth rate of per capita consumption $(C d o t)$, is based on the utility function that is fundamental to almost all modern macroeconomic models and the consumption-based asset pricing model. In this simple model, utility is equal to some function of consumption today plus the discounted utility of consumption tomorrow. If we assume that utility is logarithmic in consumption, then an equilibrium condition is that the risk-free real interest rate is equal to Cdot plus the rate of time preference. $\underline{22}$

Cdot is used with the assumption of a positive rate of time preference to get an indirect measure of the real interest rate rather than an econometric estimate of the equilibrium real rate. Such estimates are derived from observed inflation and interest rates and do not adequately control for the effect of extreme policy positions on ex post measures of real interest rates. $\underline{23}$ As shown below, the Volcker reform and the ZIRP regimes are both extreme policy settings given the Fed's inflation objective. Both regimes resulted in abnormal levels of the ex post real interest rate. Economists willing to believe that the Fed could be a cause of high real interest rates during the Volcker regime should be willing to consider the possibility that the Fed could also be a cause of low real interest rates in the ZIRP regime.

According to the consumption-based asset pricing model, the real interest rate will converge to the rate of time preference plus Cdot. Note that periods of disinflation in the United States and elsewhere are associated with high ex post real returns and positive values for Rgap. Table 1 shows that Rgap has been negative in both periods of easy monetary policy. It was -1.17 percent during the Great Inflation and -1.87 percent during the ZIRP regime. It was very high during the Volcker reform-5.06 percent-reflecting Volcker's and the FOMC's determination to end inflation (see Table 1). 
Figure 6

The Real Federal Funds Rate ( $r F F)$ and Real Per Capita Consumption Growth Rate (Cdot)

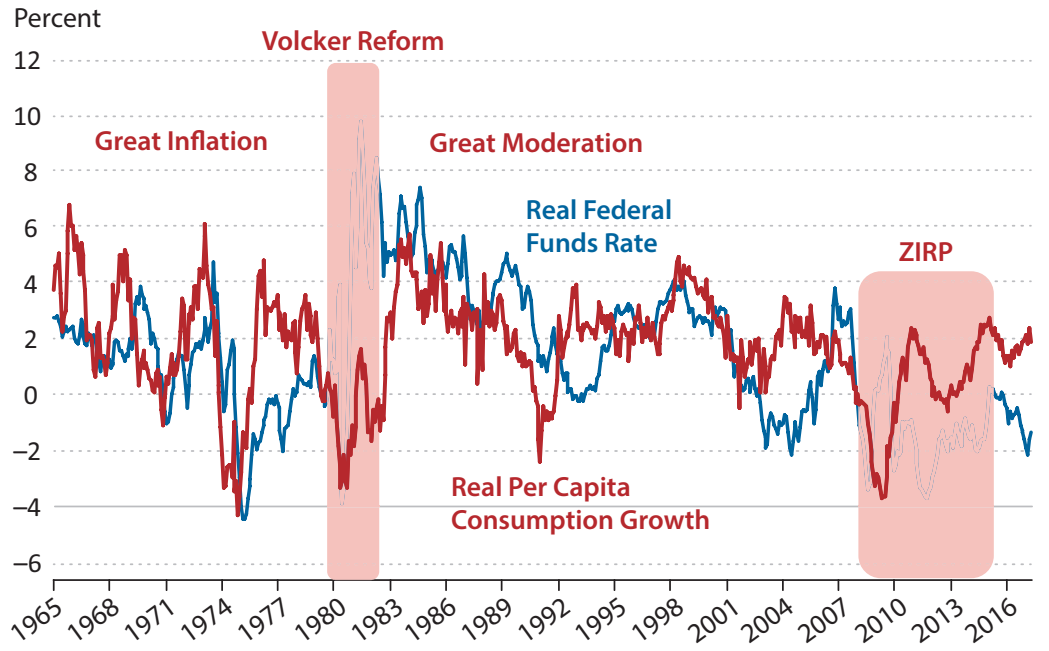

SOURCE: FRED ${ }^{\circledR}$, Federal Reserve Bank of St. Louis, DPCERAM1M225NBEA, CNP16OV, CDOT, and author's calculations.

Figure 6 plots $r F F$ and Cdot separately throughout the four regimes. During the Great Moderation, the average rates were equal. $r F F$ was higher than Cdot in the 1980s following the disinflation policy, and it was unusually low in the period from September 1992 to February 1994 when Greenspan pegged the federal funds rate target at 3 percent to stimulate employment growth (this was the first of two "jobless" recoveries). The $r F F$ is also unusually low in the period from 2002 to 2004 (the second "jobless" recovery) when the FOMC was trying to "get ahead of the curve" and prevent inflation from becoming so low that interest rates would hit the zero lower bound.

\section{CONCLUSION}

This article discusses the theory and empirical implications of four alternative monetary policy regimes that have been in place since the mid-1960s. Clearly, the alternative monetary policy regimes have had important effects on the level, variance, and covariance of datasets including measures of inflation and nominal interest rates. In periods of extreme policy settings (that is, setting the interest rate well above or well below a normal level approximately equal to the rate of time preference plus per capita consumption growth), it appears that the Fed has also been able to influence the level of real interest rates on safe assets, including ex post real returns on long-term Treasury securities. During the Volcker reform, the result was a very high real interest rate and below-trend growth in the economy. During the seven years following the 2007-08 financial crisis, the result of the ZIRP regime was a very low real interest rate and below-trend growth in the economy. I argue that it is possible that the ZIRP regime caused the low real interest rate on safe assets and subpar real consumption. 
The FOMC has begun a transition to a new policy regime or perhaps a return to an old one. As it has begun to raise the federal funds rate target, it is merely taking a rate that is well below normal to one that is closer to normal. Incoming data show that the real economy has not been damaged by slightly higher interest rates. However, the economy still remains below the trend that was predicted for potential GDP in 2007. $\underline{\text { II }}$ It seems possible that by using a floor system to control the federal funds rate in the presence of a large balance sheet, the Fed will be able to maintain many properties of the ZIRP regime even as it raises interest rates. Importantly, it may be able to keep the rate of return on safe assets below the level that is consistent with normal consumption growth and an exogenous rate of time preference for households.

In theory, we expect the monetary policy regime to have important effects on inflation and the variance-covariance structure of nominal datasets. This has been shown in earlier work and is extended to include the ZIRP regime. The Lucas critique is important when deciding how to make forecasts in a period with a new policy regime. In planning future work, the most important question is whether we can safely assume long-run monetary neutrality in periods of extreme policy positions. During the Volcker reform, real interest rates were dramatically higher than real per capita consumption growth. Real long-term returns on safe assets remain significantly below real per capita consumption growth today. Empirical evidence surveyed by Williams (2014) suggests that the Fed can influence real interest rates on long-term safe assets. What we don't know is the sign of the effect that policy-induced low interest rates have on real economic activity.

\section{NOTES}

1 Bindseil (2016) and Potter (2017) discuss details about monetary policy implementation.

2 Although the goal is defined in terms of full employment, the FRB/US and estimated dynamic stochastic general equilibrium models generally use output measured as GDP rather than unemployment as an indicator of the business cycle. Taylor (1993) developed the Taylor rule in which the federal funds rate is specified to be a function of deviations of inflation from the target and real GDP from a log linear trend.

$\underline{3}$ Gavin et al. (2015) assume persistent discount factor shocks to illustrate this mechanism.

4 Caggese and Perez-Orive (2017) show that adding intangible capital to a model with endogenously low interest rates can also lead to a subpar level of economic activity.

5 See Sargent and Wallace (1981), Leeper (1991), Sims (1994), and Woodford (1995) for early work in the area that has come to be known as the fiscal theory of the price level.

6 See work by Caballero and Hammour (1994) and Foster, Haltiwanger, and Krizon (2001) presenting theoretical and empirical support for the positive correlation between measures of turnover (a reallocation of resources to more efficient uses) and measures of productivity growth found in earlier post-WWII data.

7 Consumption rather than GDP is used as the measure of real activity for three reasons. First, it is available monthly, as are our measures of inflation and interest rates. Second, it is, in theory, the real variable that enters into household utility. And third, the growth rate of consumption is a key variable in the asset-pricing model that is used below to derive the underlying trend in the real interest rate.

8 See Mayer (1980), who reviews the history of U.S. financial policy from the end of WWII to 1980. He documents the policies and actions taken by the United States that led to inflation and the collapse of the international monetary system set up by the Bretton Woods agreement. There were signs that the system could not be sustained as early as 1961 . 
9 For perhaps the best theoretical and empirical analysis of this issue, see two articles by Cogley and Sargent (2002, 2005).

10 See Lindsey, Orphanides, and Rasche (2005) for a description of events leading to the October 6, 1979, regime change.

11 See Goodfriend (1983) for a discussion of this operating procedure and the role of the discount window in this indirect form of money supply targeting.

12 See Thornton (1988).

13 See Greenspan (2004).

14 See Taylor (2013).

15 See Fawley and Neely (2013) for a detailed discussion of QE.

16 See Gagnon and Sack (2014) for a discussion of this operating procedure.

17 See Potter (2017) for a broader discussion of this episode.

18 This floor system was complicated because not all participants in the federal funds market were allowed to have deposits at the Fed. See Bindseil (2016) for a detailed discussion of this operating procedure.

19 Another measure of the real interest rate that is relatively independent of monetary policy is the ex post return to capital (see Gomme, Ravikumar, and Rupert, 2011, 2015). Bullard (2017) uses Gomme, Ravikumar, and Rupert, $(2011,2015)$ data when explaining that it is the real interest rate on safe assets, not real returns to capital, that are abnormally low.

20 Williamson (2012) presents a macroeconomic model that captures many features of the post-crisis economy and emphasizes the role of the Fisher equation. See also Williamson (2016) for a less-formal treatment of the issue.

21 Many have argued that exogenous factors have kept the economy operating below trend, inflation low, and real interest rates low. For a sample of these arguments, see Summers (2016) and Williams (2017).

22 See Cochrane (2001, Chap. 1, Sect. 4.1) for the case with power utility.

$\underline{23}$ See, for example, Bullard (2017) and Holston, Laubach, and Williams (2016) and other articles referenced therein.

$\underline{24}$ Figure 1 in Summers (2016) shows the monotonic decline in estimates of the path of potential GDP from 2007 through 2016. This suggests a causal factor that occurred after 2007, not 30 years ago as suggested by Summers.

\section{REFERENCES}

Andolfatto, David and Martin, Fernando M. "Monetary Policy, Liquid Debt and Fiscal Constraints." Unpublished manuscript, Federal Reserve Bank of St. Louis, December 1, 2017.

Bernanke, Ben. "The Great Moderation." Speech given at the annual meetings of the Eastern Economic Association, February 20, 2004; https://www.federalreserve.gov/boarddocs/speeches/2004/20040220/default.htm.

Bindseil, Ulrich. "Evaluating Monetary Policy Operational Frameworks," in Designing Resilient Monetary Policy Frameworks for the Future. Proceedings of the Federal Reserve Bank of Kansas City Jackson Hole Economic Policy Conference, Jackson Hole, WY, August 25-27, 2016, pp. 179-277; https://www.kansascityfed.org/ /media/files/publicat/sympos/2016/2016bindseil.pdf?la=en.

Bullard, James. "An Illustrative Calculation of $r^{+}$." Federal Reserve Bank of Atlanta 22nd Annual Financial Markets Conference, Amelia Island, FL, May 8, 2017; https://www.stlouisfed.org/ /media/Files/PDFs/Bullard/ remarks/2017/Bullard Amelia Island 8 May 2017.pdf?la=en.

Caballero, Ricardo J. and Hammour, Mohamad L. "The Cleansing Effect of Recessions." American Economic Review, December 1994, 84(5), pp. 1350-68.

Caggese, Andrea and Perez-Orive, Ander. "Capital Misallocation and Secular Stagnation." Finance and Economics Discussion Series 2017-009, Board of Governors of the Federal Reserve System, 2017; https://doi.org/10.17016/FEDS.2017.009. 
Cochrane, John H. Asset Pricing. Princeton University Press, 2001.

Cogley, Timothy and Sargent, Thomas J. "Evolving Post-World War II US Inflation Dynamics," in B.S. Bernanke and K. Rogoff, eds., NBER Macroeconomics Annual 2001. Volume 16. MIT Press, 2002, pp. 331-73.

Cogley, Timothy and Sargent, Thomas J. "Drifts and Volatilities: Monetary Policies and Outcomes in the Post WWII US." Review of Economic Dynamics, April 2005, 8(2), pp. 262-302; https://doi.org/10.1016/j.red.2004.10.009.

Cooke, Diana A. and Gavin, William T. "Three Scenarios for Interest Rates in the Transition to Normalcy." Federal Reserve Bank of St. Louis Review, First Quarter 2015, 97(1), pp. 1-24; https://files.stlouisfed.org/files/htdocs/publications/review/2015/q1/1-24CookeGavin.pdf.

DeLong, J. Bradford. "America's Peacetime Inflation: The 1970s," in C. Romer and D.H. Romer, eds., Reducing Inflation: Motivation and Strategy. University of Chicago Press, 1997, pp. 247-80.

Fawley, Brett W. and Neely, Christopher J. "Four Stories of Quantitative Easing." Federal Reserve Bank of St. Louis Review, January-February 2013, 95(1), pp. 51-88; https://files.stlouisfed.org/files/htdocs/publications/review/13/01/Fawley.pdf.

Foster, Lucia; Grim, Cheryl and Haltiwanger, John. "Reallocation in the Great Recession: Cleansing or Not?" in D. Card and A. Mas, organizers, Labor Markets in the Aftermath of the Great Recession. National Bureau of Economic Research, 2016, pp. 293-331.

Foster, Lucia; Haltiwanger, John C. and Krizan, C.J. "Aggregate Productivity Growth: Lessons from Microeconomic Evidence," in Charles R. Hulten, Edwin R. Dean and Michael J. Harper, eds., New Developments in Productivity Analysis. University of Chicago Press, 2001, pp. 303-72; https://doi.org/10.7208/chicago/9780226360645.001.0001.

Gagnon, Joseph E. and Sack, Brian. Monetary Policy with Abundant Liquidity: A New Operating Framework for the Federal Reserve. Peterson Institute for International Economics, 2014.

Gavin, William T.; Keen, Benjamin D.; Richter, Alexander W. and Throckmorton, Nathaniel A. "The Zero Lower Bound, the Dual Mandate, and Unconventional Dynamics." Journal of Economic Dynamics \& Control, 2015, 55, pp. 14-38; https://doi.org/10.1016/j.jedc.2015.03.007.

Gavin, William T. and Kydland, Finn E. "Endogenous Money Supply and the Business Cycle." Review of Economic Dynamics, 1999, 2(2), pp. 347-69; https://doi.org/10.1006/redy.1998.0055.

Gavin, William T. and Kydland, Finn E. "The Nominal Facts and the October 1979 Policy Change." Federal Reserve Bank of St. Louis Review, 2000, 82(6), pp. 39-61; https://files.stlouisfed.org/files/htdocs/publications/review/00/11/0011wg.pdf.

Gomme, Paul; Ravikumar, B. and Rupert, Peter. "The Return to Capital and the Business Cycle." Review of Economic Dynamics, 2011, 14(2), pp. 262-78; https://doi.org/10.1016/j.red.2010.11.004.

Gomme, Paul; Ravikumar, B. and Rupert, Peter. "Secular Stagnation and Returns on Capital." Economic Synopses, 2015, No. 19, August 18, 2015.

Goodfriend, Marvin. “Discount Window Borrowing, Monetary Policy, and the Post-October 6, 1979, Federal Reserve Operating Procedure." Journal of Monetary Economics, 1983, 12(3), pp. 343-56; https://doi.org/10.1016/0304-3932(83)90058-2.

Greenspan, Alan. "Risk and Uncertainty in Monetary Policy." American Economic Review, 2004, 94(2), 33-40; https://doi.org/10.1257/0002828041301551.

Holston, Kathryn; Laubach, Thomas and Williams, John C. "Measuring the Natural Rate of Interest: International Trends and Determinants." Working Paper 2016-11, Federal Reserve Bank of San Francisco, December 2016; https://www.frbsf.org/economic-research/files/wp2016-11.pdf. Forthcoming in Journal of International Economics.

Leeper, Eric. "Equilibria under 'Active' and 'Passive' Monetary Policies." Journal of Monetary Economics, 1991, 27(1), pp. 129-47; https://doi.org/10.1016/0304-3932(91)90007-B.

Lindsey, David E.; Orphanides, Athanasios and Rasche, Robert H. "The Reform of October 1979: How It Happened and Why." Federal Reserve Bank of St. Louis Review, March-April 2005, 87(2, Part 2), pp. 187-235; https://files.stlouisfed.org/files/htdocs/publications/review/13/11/lindsey.pdf.

Mayer, Martin. The Fate of the Dollar. Times Books, 1980. 
Nelson, Edward. "The Great Inflation of the Seventies: What Really Happened?" B.E. Journal of Macroeconomics: Advances in Macroeconomics, 2005, 5(1), pp. 1-48; https://doi.org/10.2202/1534-6013.1297.

Potter, Simon. "Implementing Monetary Policy with the Balance Sheet." Speech at the ECB workshop Money Markets, Monetary Policy Implementation, and Central Bank Balance Sheets, Frankfurt Am Main, Germany, November 6, 2017; https://www.newyorkfed.org/newsevents/speeches/2017/pot171106.

Sargent, Thomas J. "Reactions to the Berkeley Story." October 21, 2002; http://www.tomsargent.com/research/romers3.pdf.

Sargent, Thomas J. and Wallace, Neil. "Some Unpleasant Monetarist Arithmetic." Federal Reserve Bank of Minneapolis Quarterly Review, 1981, 5(3), pp. 1-17; https://www.minneapolisfed.org/research/qr/qr531.pdf.

Sims, Christopher A. "A Simple Model for Study of the Determination of the Price Level and the Interaction of Monetary and Fiscal Policy." Economic Theory, 1994, 4(3), pp. 381-99; https://doi.org/10.1007/BF01215378.

Stock, James H. and Watson, Mark W. "Has the Business Cycle Changed and Why?" in M. Gertler and K. Rogoff, eds., NBER Macroeconomics Annual 2002. Volume 17. MIT Press, 2003.

Summers, Lawrence H. "Secular Stagnation and Monetary Policy." Federal Reserve Bank of St. Louis Review, Second Quarter 2016, 98(2), pp. 93-110; https://files.stlouisfed.org/files/htdocs/publications/review/2016-06-17/secular-stagnation-and-monetary-policy.pdf.

Taylor, John B. “Discretion versus Policy Rules in Practice." Carnegie-Rochester Conference Series on Public Policy, 1993, 39(1), pp. 195-214; https://doi.org/10.1016/0167-2231(93)90009-L.

Taylor, John B. "Reviewing the 'Too Low for Too Long' Evidence." Economics One, October 19, 2013; https://economicsone.com/2013/10/19/reviewing-the-too-low-for-too-long-evidence.

Thornton, Daniel L. "The Borrowed-Reserves Operating Procedure: Theory and Evidence." Federal Reserve Bank of St. Louis Review, January-February 1988, 70(1), pp. 30-54; https://files.stlouisfed.org/files/htdocs/publications/review/88/01/Borrowed_Jan_Feb1988.pdf.

Williams, John C. "Monetary Policy at the Zero Lower Bound: Putting Theory into Practice." Hutchins Center on Fiscal \& Monetary Policy at Brookings, January 16, 2014.

Williams, John C. "The Global Growth Slump: Causes and Consequences." Federal Reserve Bank of San Francisco Economic Letter, 2017-19, July 3, 2017; https://www.frbsf.org/economic-research/publications/economic-letter/2017/july/global-growth-slump-causes-consequences-speech/.

Williamson, Stephen D. "Liquidity, Monetary Policy, and the Financial Crisis: A New Monetarist Approach." American Economic Review, 2012, 102(6), pp. 2570-605; https://doi.org/10.1257/aer.102.6.2570.

Williamson, Stephen D. “Neo-Fisherian Denial.” New Monetarist (blog), April 14, 2016.

Woodford, Michael. "Price Level Determinacy Without Control of a Monetary Aggregate." Carnegie-Rochester Conference Series on Public Policy, 1995, 43, pp. 1-46; https://doi.org/10.1016/0167-2231(95)90033-0. 
